\title{
EDITOR'S TRIBUTE
}

\author{
Elizabeth Dolomont
}

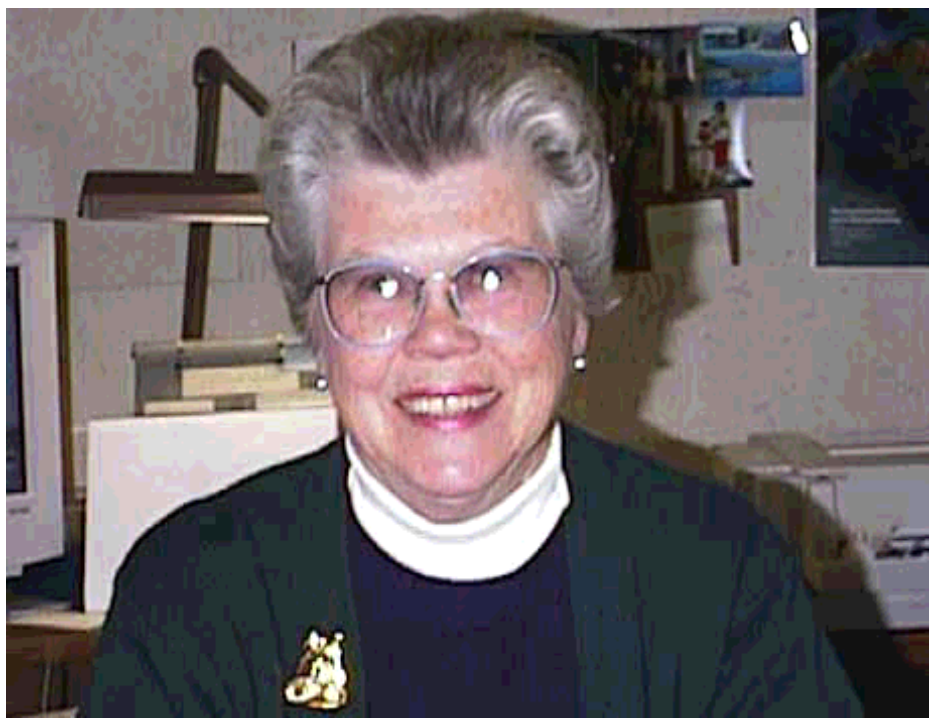

Elizabeth Dolomont joined the Cowles Foundation as my secretary in 1984 and retired in December 1997. Over the intervening 14 years, Elizabeth has been my personal assistant at Yale in running the journal Econometric Theory.

At the time Elizabeth joined me, ET had been established and plans for publication were well under way, but our first issue in March 1985 was still some time off and there was much to be done, including the constitution of our Editorial Board, the preparation of leaflets, editorial policy statements, advertising copy, the design of stationery, acknowledgement cards, organization of filing systems, and the construction of a computerized database that would enable us to track submissions, refereeing, and the full editorial process electronically. The last matter, of course, was so much more difficult in the early 1980's than it is today. With all this work to do, Elizabeth soon became an integral part of the ET project and devoted herself to helping me manage this new enterprise.

Since 1984,Elizabeth has been a vital element in the conduct of every aspect of our daily business. She has worked tirelessly and with great devotion to ET and has made the running of the journal a pleasure. Even at our busiest moments, and there have been plenty of these, Elizabeth always took the time to be considerate and helpful to others. To me, she was a helpmate and colleague extraordinaire. The smooth running and success of ET is in no small part due to her many efforts. 
Elizabeth is well known personally to many of our authors and readers who have passed through Yale in the last 14 years. Some of these are former Yale econometrics students, whom Elizabeth has helped during their student years and are well aware of the central role she has played in looking after graduate students. Others are colleagues from outside Yale whom Elizabeth was always delighted to meet and help to feel at home here. Many of those she has not met have corresponded with her or talked with her on the telephone and are acquainted with her delightfully charming and engaging manner.

For myself, working with Elizabeth has been one of the privileges I have been very fortunate to have had at Yale. It is a great understatement to say I miss her greatly and it is a pleasure to take this opportunity to thank Elizabeth now for all she has done to help me in running $E T$, for her uplifting good spirits as an office companion, and for helping me to launch the ET enterprise and make it the enjoyable one that it has been for so long.

I am sure that all of you who know Elizabeth will join me in wishing her well in her retirement.

Peter C.B. Phillips

December 1997 